UNITED STATES DEPARTMENT OF THE INTERIOR GEOLOGICAL SURVEY

\title{
Arsenic and Gold Mineralization in the \\ McF arland Canyon-Story Mine Area, Maricopa County, Arizona
}

by

S. P. Marsh

Open File Report 83-442

1983

This report is preliminary and has not been edited or reviewed for conformity with U.S. Geological Survey standards or nomenclature 
Table of Contents

Introduction ............................................

Ge ochem istry...........................................6

Genesis ............................................... 6

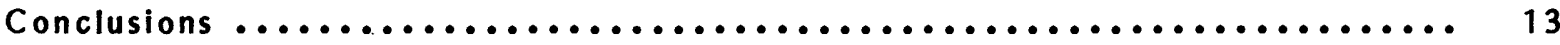

References Cited ........................................ 13

Appendix.............................................. 14

\section{Tables}

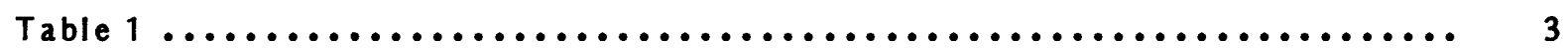

Table $2 \ldots \ldots \ldots \ldots \ldots \ldots \ldots \ldots \ldots \ldots \ldots \ldots \ldots \ldots \ldots \ldots \ldots \ldots \ldots \ldots \ldots \ldots \ldots \ldots$

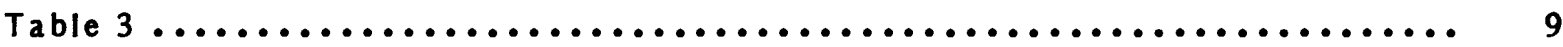

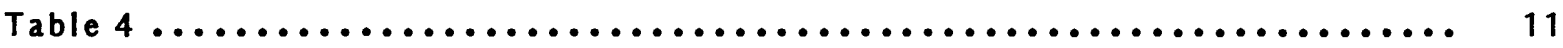

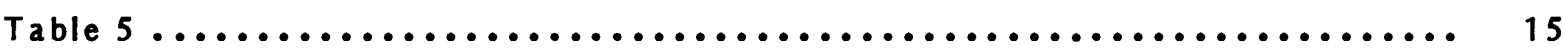

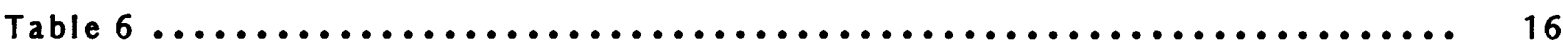

Illustrations

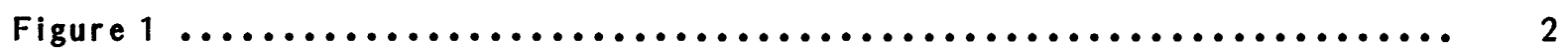

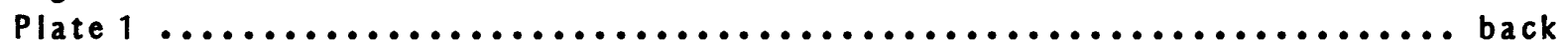




\section{Introduction}

McFarland Canyon is an east-west trending drainage in the Tonto National Forest in the northeast corner of $M$ aricopa County, Arizona, $8 \mathrm{~km} \mathrm{(5-1/2} \mathrm{mi})$ north of the small town of Sunflower, Arizona. The western half of McFarland Canyon lies within the Mazatzal Wilderness area and much of the area discussed in this report lies just west or astride the eastern boundary of the wilderness. Access to the area is via State Route 87 north from Phoenix and unimproved U.S. Forest Service and mining roads (fig. 1). The area is one of high relief ranging from $1340 \mathrm{~m}(4400 \mathrm{ft})$ to $1645 \mathrm{~m}(5400 \mathrm{ft})$ with deeply incised streams. The area is densely vegetated with scrub oak and brush; occassional stands of pine occur in the canyon bottoms.

The McFarland Canyon area lies just north of the Sunflower and Story mines and most likely can be considered as part of the Sunflower mining district. Reconnaissance geology and geochemistry of the Mazatzal Wilderness area defined an area of base and precious metal resources at the Story Mine (Wrucke and others, 1983). In September 1982 the reconnaissance work was extended northward $0.8 \mathrm{~km}(0.5$ $\mathrm{mi}$ ) from the Story mine and a detailed geochemical study of McFarland Canyon was undertaken. This report discusses the results of that study and proposes a model for the observed mineralization.

$M c F a r l a n d$ Canyon cuts through a sequence of metavolcanic and metasedimentary rocks belonging to the Alder Formation of Proterozoic $X$ age. The Alder Formation is exposed in a tightly compressed syncline and comprises weakly to stongly foliated sandstone, graywacke, shale, conglomerate, rhyodacite and rhyolite tuffs and flows, and subordinate mafic volcanic rocks (Plate 1 ). These rocks have been metamorphosed to the greenschist facies of regional metamorphis and intruded by rhyolite porphyry dikes and sills. The Alder Formation has been faulted off to the north by a northeast trending major structure, the Sheep Mountain Fault (Fig. 1) This fault separates the Alder Formation from the Proterozoic Payson Granite, it's extrusive rhyolite, and the overlying Proterozoic $X$ quartzites. Payson Granite outcrops approximately $2 \mathrm{~km}(1.3 \mathrm{mi})$ northwest of McFarland Canyon. The Payson Granite outcrops in over $100 \mathrm{sq} \mathrm{km}$ ( $39 \mathrm{sq} \mathrm{mi}$ ) of the Mazatzal Wilderness, makes up almost the entire Hells Gate Roadless Area $12 \mathrm{~km}$ $(8 \mathrm{mi})$ to the east and is thought to underlie much of this part of Arizona. Going southwards and upsection from McFarland Canyon to the Story mine the progression is gradational from fine-grained greenish to purplish tuffaceous meta-sediments with volcanic clasts, to a coarse-grained volcanoclastic graywacke, to tuffaceous metasediments (aw) at the Story mine. Rhyolite dikes (ip) have intruded the metasediments and trend northeast, roughly parallel to, but cross cutting, foliation (bedding). The sequence of geologic events in the McFarland Canyon area, based on field observations, were as follows: (1) deposition of the volcanic and volcanogenic rocks of the Alder Formation, (2) regional metamorphis $m$ and structural deformation, (3) intrusion of mineralized rhyolite dikes, (4) introduction of quartz-arsenopyrite veins, and (5) later possible remobilization of mineralization by Tertiary (?) heating.

About 4 days in the latter part of September 1982 were spent in a geochemical study of the area to assess the potential for gold mineralization. Rock samples from prospect pits and small mines were collected and analyzed to determine the metal suite associated with the observed mineralization. Samples of metasediments and rhyolite dikes also were analyzed to determine the extent of the mineralization and alteration. Table 1 gives a brief description of all rock samples discussed in this report. 


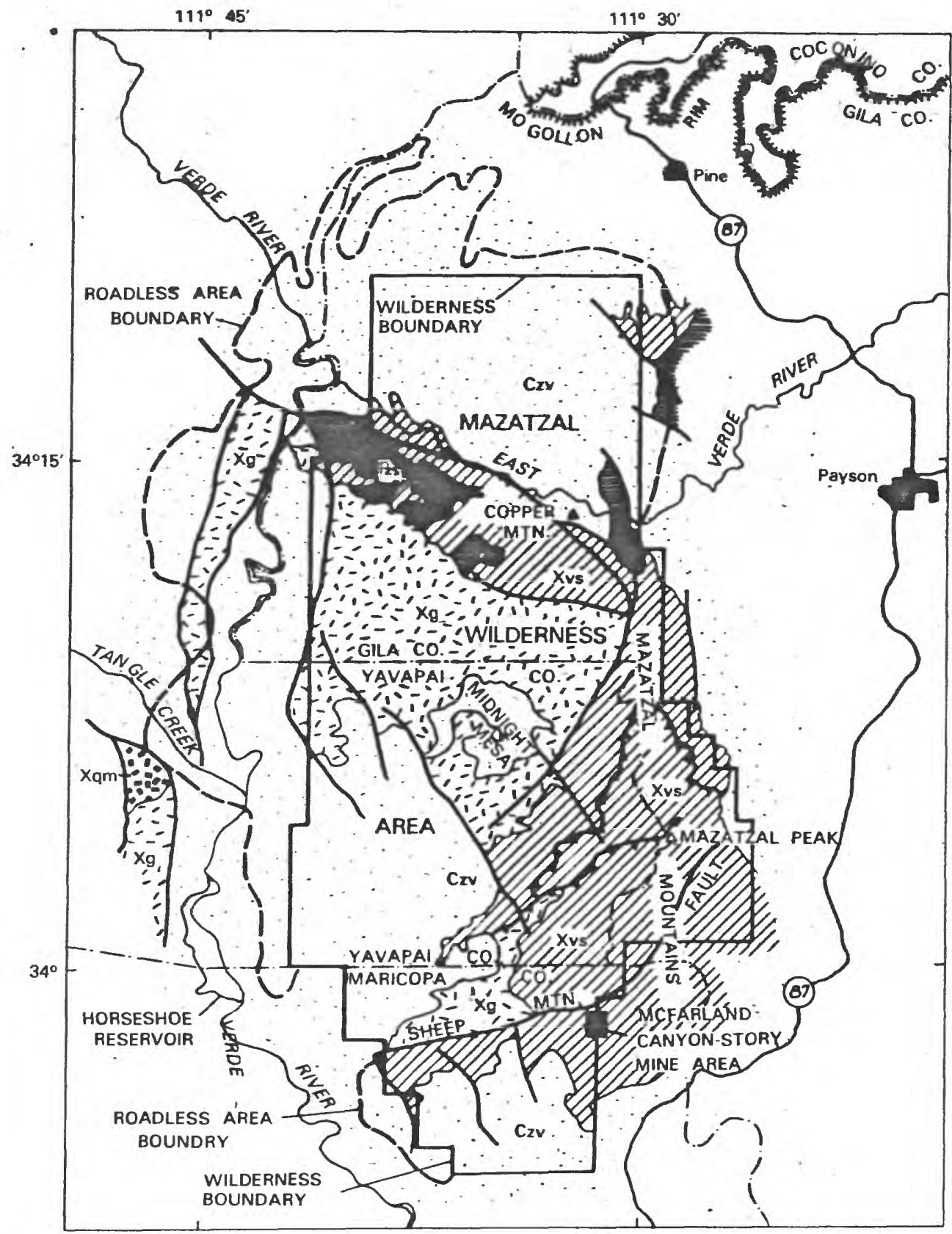

CORRELATION OF MAP UNITS

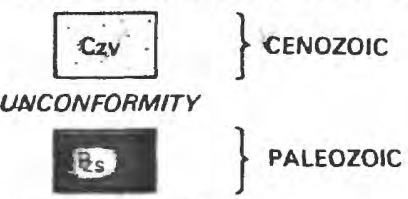

UNCONFORMITY

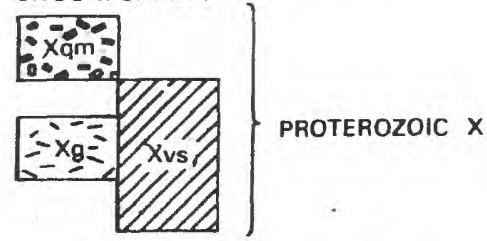

DESCRIPTION OF MAP UNITS

Czv Volcanic and sedimentary rocks

Bs Sedimentary rocks

Xam Quartz monzonite

Xvs Volcanic and sedimentary rocks

Xg Payson Granite
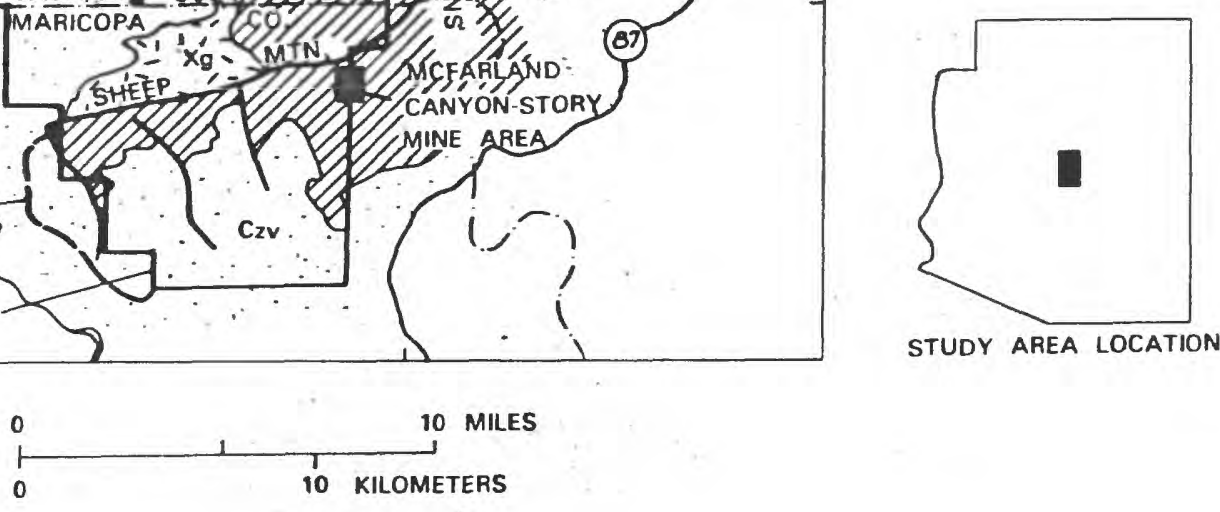

Figure 1. Map showing generalized geology of the Mazatzal Wilderness Area and the location of the McFarland Canyon-Story Mine area 
Table 1.--Description of rock samples

Sample No. Description

McFarland Canyon-Story Mine Area

MZ495R

MZ495RA

MZ495RB

MZ495RC

MZ536R

MZ537R

MZ537RA

MZ538R

MZ538RA

MZ538RB

MZ538RC

MZ538RD

MZ538RE

MZ539R

MZ540R

MZ540RA

MZ541R

MZ542R

MZ543R

MZ543RA

MZ544R

MZ544RA

MZ544RB

MZ544RC
Altered metasediments with $\mathrm{Fe}$ oxides and scorodite $\left(\mathrm{FeAsO}_{4} \cdot 2 \mathrm{H}_{2} \mathrm{O}\right)$ from hanging wall

Altered metasediments with Fe oxides and scorodite from foot wal1

Altered metasediments with Fe oxides and scorodite from foot wall

Gossan from outcrop $50 \mathrm{~m}(150 \mathrm{ft})$ southwest from MZ495RB

Rhyolite from prospect; very altered with Fe oxide staining throughout; veinlets and masses of arsenopyrite.

Adit in McFarland Canyon; Fe oxide fracture fillings in rhyolite sill.

Rhyolite pieces from dump; very altered, bleached with pyrite relics; some quartz eyes.

Clastic metasedimentary rock with abundant pyrite crystals and irregular masses throughout.

Sample of rhyolite with abundant arsenopyrite.

Relatively pure arsenopyrite from margin of vein.

Vein approximately $14 \mathrm{~cm}$ wide; disseminated arsenopyrtie and some relic pyrite cubes.

$2 \mathrm{~cm}$ selvage on top side of vein that has mostly arsenopyrite and secondary arsenic minerals.

Sedimentary rock, fine grained, very Fe oxide altered, greenish with visible pyrite and arsenopyrite.

Altered rhyolite with abundant limonite after pyrite and $\mathrm{Fe}$ oxides; some sericitic alteration.

Quartz vein with Fe oxides in cavities from Story mine area.

Siliceous sulfide bearing vein at caved adit with abundant As and $\mathrm{Fe}$ oxides.

Large boule quartz vein, abundant cavities containing Fe oxides. Gossan with sulfides and secondary arsenic minerals.

Rhyolite with Fe oxides, secondary copper stains, some disseminated arsenopyrite.

Hard dense rhyolite, greenish with abundant disseminated arsenopyrite.

Siliceous green fine-grained metasediments with abundant pyrite. Quartz rich rock finely laminated with Fe oxides and secondary arsenic minerals (scorodite).

Massive sulfide, arsenopyrite and pyrite.

Quartz vein system with massive sulfides, both pyrite and arsenopyrite. 
Table 1.--Description of rock samples--continued

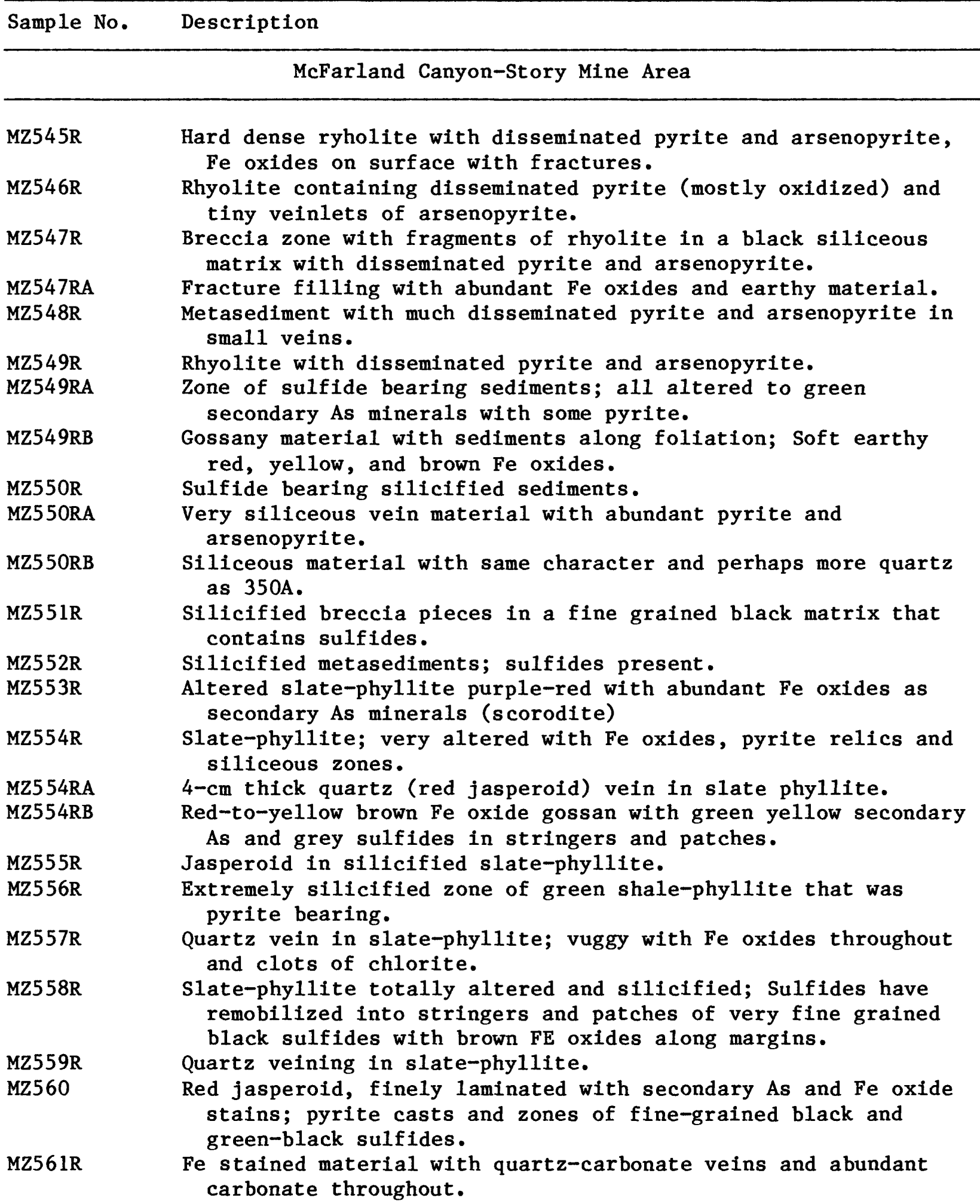


Table 1.--Description of rock samples--continued

Sample No. Description

McFarland Canyon-Story Mine Area

MZ562R

Quartz zone in greywacke with brown jasperoid, $\mathrm{Mn}($ ?) and fine grained chlorite, some relic pyrite along fractures.

MZ563R Siliceous zone in dark fine-grained phyllitic material stained red and brown with Fe oxides.

MZ564R Altered zone in phyllitic material; all Fe oxide stained with pyrite relics and casts throughout; silicified.

MZ564RA Bands and lenses of red jasper, black fine-grained siliceous zones and yellow and brown Fe oxides, some relic pyrite.

MZ564RB Quartz vein with gossan and cinnabar as small blebs associated with quartz veins; some evidence of As and secondary yellowgreen stains.

MZ564RC Schist with abundant silica and disseminated sulfides, mostly pyrite; pyrite is all fresh.

MZ565R Quartz-chlorite vein with Fe oxides in black siliceous country rock.

Mazatzal Wilderness Area

$\begin{array}{ll}\text { MZ442R } & \text { Arsenopyrite from Stingy Lady mine } \\ \text { MZ442RA } & \text { Arsenopyrite from Stingy Lady mine } \\ \text { MZ442RB } & \text { Arsenopyrite from Stingy Lady mine } \\ \text { MZ442RC } & \text { Scorodite from Stingy Lady mine } \\ \text { MZ442RD } & \text { Scorodite from Stingy Lady mine } \\ \text { MZ442RI } & \text { Scorodite from Stingy Lady mine } \\ \text { MZ454RB } & \text { Green and yellow secondary minerals (scorodite) from shear zone } \\ \text { MZ476RI } & \text { Arsenopyrite from shear zone }\end{array}$

Hells Gate Roadless Area

HG091RA Arsenopyrite and secondary copper minerals.

MZ491RA Altered metasediments with sericite and scorodite. 


\section{Geochemistry}

Samples taken in this study were of two types-obviously mineralized rocks and selected rock types occurring in the area.

An examination of the chemical data (see Appendix) revealed a distinctive geochemical suite common to all mineralized areas seen in this study. This suite is one that has been recognized in samples from mineralized areas in other parts of the Mazatzal Wilderness area. Our data also indicates that the suite is most likely related to the intrusion of the Payson Granite. The suite consists of major a mounts of arsenic, copper, lead, and antimony in varying proportions depending on the mineralogy of the sample, significant amounts of gold, silver, mercury, bismuth, zinc, and tellurium, and associated boron, beryllium, tin, and cadmium. The sulfide minerals observed in these areas are arsenopyrite, tetrahedrite, and tenantite, sometimes together, but, commonly as a single mineral species. The geochemical suite, however, is always present in the rocks of mineralized areas. In McFarland Canyon arsenopyrite was the observed sulfide mineral.

\section{Genesis}

Initial field observations suggested a possible volcanogenic origin for the mineralization. The host rocks offer a compelling argument for a volcanogenic model; a sequence of volcanic and volcanoclastic sediments with rhyolite dikes and sills. Also, approximately $0.8 \mathrm{~km}$ $(0.5 \mathrm{mi})$ southeast of the Story mine, up section, lies a banded iron formation several hundred meters (feet) thick (ac). However, the volcanogenic model becomes less convincing upon close scrutiny. The rhyolite dikes are mineralized in the area of the Story mine and the central part of $M c F a r l a n d$ Canyon but are barren to the northeast. The dikes clearly postdate metamorphism and structural deformation of the Alder formation. They are not foliated themselves and cut across foliation (bedding) of the country rocks. Zones of brecciation occur at their margins. To further test the volcanogenic model, several samples of the banded iron formation were analyzed to see if it was mineralized as would be anticipated in a volcanogenic model. No mineralization was detected with the exception of mercury and, more significantly, no trace was found of the geochemical suite that occurs in the mineralized areas. It was also noted that there seemed to be two stages of sulfide mineralization in the McFarland Canyon area. The first stage was pyrite that is disseminated in and is temporally related to the intrusion of the rhyolite dikes and, in general, does not contain the favorable geochemical suite. The second stage was arsenopyrite in quartz veins. These veins cut the rhyolite dikes and the foliation (bedding) of the country rocks at low angles. If the mineralization is of volcanogenic origin, then somewhere near the center of the mineralized zone we would expect to find a breccia pipe or some fractured zone indicating venting of the system; none was found. We would expect to find mineralization in the banded iron formation as noted above, but none was found. Most of the arsenopyrite occurs in quartz veins and none of it is considered to be massive sulfide (the most massive arsenopyrite seen was in one area of quartz veining where a $10 \mathrm{~cm}$ (4 in.) thick vein was observed). This series of observations leads to the conclusion that the mineralization in McFarland Canyon is not volcanogenic, is younger than the country rocks, and must be related to some later mineralizing event.

Several interesting observations about the mineralization at McFarland Canyon can be made from the analyses of the rock samples (Appendix). The arsenic content is consistently high. Many samples contain arsenopyrite, but most samples without visible arsenopyrite also contain anomalously high amounts of arsenic. The lowest arsenic value obtained was 70 ppm (parts per million) in two samples; one of pyrite bearing volcanoclastic metasediment with no visible arsenopyrite (MZ538R) and one of altered rhyolite with oxidized pyrite and minor arsenopyrite (MZ546R). The rest of the values for arsenic ranged from $150 \mathrm{ppm}$ to greater than $1 \%$. High arsenic values were also found in samples from the Story 
mine $0.8 \mathrm{~km}(0.5 \mathrm{mi})$ to the south and in rock samples from many of the mineralized areas of the Proterozoic Payson Granite and surrounding Proterozoic metasediments during the study of the Mazatzal Wilderness (S. Marsh, unpub. data). The presence of arsenic is often manifested by greenish-yellow stains and coatings of the iron arsenate, scorodite. Arsenopyrite veins contain the highest gold values found in the McFarland Canyon area and Table 2 compares samples from McFarland Canyon with those from the Story mine and from the nearby Mazatzal Wilderness and Hells Gate Roadless Area. These samples exhibit the geochemical suite found in all mineralized areas examined.

Often high arsenic and gold values were detected in the oxidized environment where no primary sulfides were found but where secondary minerals were abundant. These areas of secondary mineralization commonly are near or adjacent to areas of sulfide-bearing rocks and they also contain arsenic, copper, lead, and antimony. The Story mine area is an example of this type of secondary arsenic mineralization. The mine workings are inaccessible, but it can be assumed that sulfides were encountered at depth. Analyses of secondary arsenic mineralization from the Story mine, $M$ cFarland Canyon, areas in the Mazatzal Wilderness and from areas just south of the Hells Gate Roadless Area (Table 3) show that gold is often more abundant in these samples than in the unoxidized sulfide samples. Gold was not visible in any of the samples.

Upon even the most casual observation, alteration and oxidation is obvious in the M cFarland Canyon-Story mine area. The rocks of the area appear leached and bleached especially in and near the areas of the rhyolite dikes. This is more pervasive around the Story mine than in $M$ cFarland Canyon and is reflected in the mineralization seen. Most sulfide mineralization around the Story mine has been oxidized while most sulfide mineralization in M cFarland Canyon remains unoxidized. In many places in the McFarland Canyon-Story mine area the original pyrite in the system has weathered to iron oxides, leaving relic pyrite as hematite or limonite. Often only cubic casts are left in the bleached metasediments, sometimes filled with earthy iron oxides. Sericitic alteration in the rhyolite dikes was noted at several localities. In addition to the sericitic alteration, the whole McFarland CanyonStory mine area has undergone extreme silicification. Quartz veins and indications of quartz veining are seen everywhere. The hilltop above the Story mine contains a vertically dipping zone of silicified metasediments 3 to $5 \mathrm{~m}(10-15$ $f t$ ) wide that strikes N. $50^{\circ} \mathrm{E}$. for approximately $100 \mathrm{~m}(300 \mathrm{ft})$. This zone, although totally silicified, still retains much of the metasedimentary features as bedding, volcanic clasts, and pyrite casts. Quartz veins and stringers cut this unit in every direction and range from several millimeters to several centimeters ( 0.2 to 1.0 in.) wide. Intense chloritization of the metasediments is common in areas of silicification. Jasperoid is also $\mathrm{common}$ in the area of the Story mine as red and red-brown zones and bands with yellow and yellow-brown iron oxides on fractures.

The quartz veins in the $M c F$ arland Canyon-Story mine area range from discrete veins to pods and stringers. Some are sulfide bearing, vuggy, and "eaten out" appearing where the sulfides have been removed. Chloritized metasedimentary rock fragments have been caught up in the veins near the Story mine. Some fragments are further altered to earthy darkbrown iron oxides and finally the quartz veins and pods are left with voids as the iron oxides weather away. All stages of this process can be seen in the area of the mine.

The silicification in the $M c F$ arland Canyon-story mine area extends for as much as several kilometers (miles). Silicified rocks were observed as far as $3 \mathrm{~km}$ (2 $\mathrm{mi}$ ) to the south where a sample (MZ565R, Tables 1 and 6) contained traces of the geochemical suite related to the mineralization at the M cFarland CanyonStory mine area. 
Table 2.--Atomic absorption analyses of arsenopyrite bearing samples from McFarland Canyon, from the Story mine, from selected areas in the Mazatzal Wilderness Area, and from an area south of the Hells Gate Roadless Area, Maricopa, Gila, and Yavapai Counties, Arizona

[A11 values reported in parts per million. See Table 1 for description of samples. (The following qualifiers are used in reporting the data: $\mathrm{N}$, not detected at the limit of determination; <, detected, but below the limit of reproducible determination for the standards used; $>1$, present at greater than 1 percent and exceeded the detection limits of the method of analysis; and, ( ), interference in analysis.)]

\begin{tabular}{rrrrlrrrrrr}
\hline Sample & $\mathrm{Te}$ & $\mathrm{Au}$ & $\mathrm{Ag}$ & $\mathrm{Hg}$ & $\mathrm{Bi}$ & $\mathrm{Pb}$ & $\mathrm{Cu}$ & $\mathrm{Zn}$ & $\mathrm{Sb}$ & $\mathrm{Cd}$ \\
\hline \multicolumn{1}{c}{ McFarland Canyon } \\
\hline MZ536R & 0.9 & 0.2 & 0.6 & 0.12 & $\mathrm{~N}$ & 10 & 60 & 20 & $\mathrm{~N}$ & 0.2 \\
538RB & 17.0 & 7.0 & $>1$ & 4.6 & 470 & $>1$ & $>1$ & $>1$ & $>1$ & 56 \\
538RC & 11.0 & 0.3 & 9 & 0.02 & 1,000 & $>1$ & 290 & 80 & 300 & 2.7 \\
538RD & 16.0 & 3.9 & 31 & 0.16 & 680 & $>1$ & 650 & 450 & 450 & 7.3 \\
544RB & 0.9 & 17.0 & $>1$ & 0.5 & 350 & $>1$ & $>1$ & 250 & $>1$ & 12
\end{tabular}

Story Mine

\begin{tabular}{|c|c|c|c|c|c|c|c|c|c|}
\hline MZ540RA & $<0.1$ & 2.8 & $>1$ & 1.6 & $\mathrm{~N}$ & $>1$ & 290 & 500 & 180 \\
\hline $554 \mathrm{RB}$ & 24.0 & 13.0 & $>1$ & 1.2 & 190 & $>1$ & 470 & 140 & 110 \\
\hline
\end{tabular}

Mazatzal Wilderness Area

\begin{tabular}{cccccrrrrrr}
\hline MZ442R & $(9.3)$ & 0.05 & 435 & 38.0 & 1600 & 3,000 & 69,000 & 2,400 & $>1$ & 90 \\
442RA & 1.3 & 0.1 & 135 & 0.2 & 680 & 8,300 & 5,400 & 400 & $>1$ & 25 \\
442RB & $(5.5)$ & 0.1 & 575 & 90.0 & 4,300 & 30,000 & 77,000 & 7,800 & $>1$ & 170 \\
476RI & 1.0 & 0.6 & 3 & $(2.0)$ & 440 & 180 & 500 & 60 & 5,200 & 2 \\
\hline
\end{tabular}

He11s Gate Roadless Area

$\begin{array}{lllllllllll}\text { HG091RA } & 1.5 & 4.9 & 6 & 890 & 70 & 240 & >1 & 400 & 5,800 & 49\end{array}$


Table 3.--Atomic absorption analysis of secondary arsenic mineralization in rocks from McFarland Canyon, the Story mine, from selected areas in the Mazatzal Wilderness Area, and from an area south of the He1ls Gate Roadless Area, Maricopa, Gila, and Yavapai Counties, Arizona

[A11 values reported in parts per million. See Table 1 for description of samples. (The following qualifiers are used in reporting the data: $\mathrm{N}$, not detected at the limit of determination; <, detected, but below the limit of reproducible determination for the standards used; $>1$, present at greater than 1 percent and exceeded the detection limits of the method of analysis; and, ( ), interference in analysis.)]

\begin{tabular}{|c|c|c|c|c|c|c|c|c|c|c|c|}
\hline Sample & $\mathrm{Te}$ & $\mathrm{Au}$ & $\mathrm{Ag}$ & $\mathrm{Hg}$ & $\mathrm{Bi}$ & $\mathrm{Pb}$ & $\mathrm{Cu}$ & $\mathrm{Zn}$ & $\mathrm{Sb}$ & Cd & As \\
\hline \multicolumn{12}{|c|}{ McFarland Canyon } \\
\hline $\begin{array}{r}\text { MZ544RA } \\
\text { 547RA } \\
\text { 549RA }\end{array}$ & $\begin{array}{l}2.7 \\
0.7 \\
0.2\end{array}$ & $\begin{array}{l}0.25 \\
0.4 \\
2.0\end{array}$ & $\begin{array}{r}12 \\
0.8 \\
3.6\end{array}$ & $\begin{array}{l}0.42 \\
0.40 \\
0.40\end{array}$ & $\begin{array}{r}120 \\
4 \\
20\end{array}$ & $\begin{array}{r}170 \\
320 \\
20\end{array}$ & $\begin{array}{r}75 \\
70 \\
230\end{array}$ & $\begin{array}{r}60 \\
350 \\
70\end{array}$ & $\begin{array}{l}200 \\
210 \\
130\end{array}$ & $\begin{array}{l}1.3 \\
2.2 \\
0.1\end{array}$ & $\begin{array}{r}300 \\
>1 \\
1,100\end{array}$ \\
\hline \multicolumn{12}{|c|}{ Story Mine } \\
\hline $\begin{array}{c}\text { MZ495R } \\
\text { 495RA } \\
\text { 495R B } \\
495 \mathrm{RC} \\
553 \mathrm{R} \\
554 \mathrm{R}\end{array}$ & $\begin{array}{l}1.1 \\
0.8 \\
1.2 \\
1.5 \\
0.6 \\
0.4\end{array}$ & $\begin{array}{l}2.25 \\
4.9 \\
<0.05 \\
7.1 \\
8.0 \\
1.5\end{array}$ & $\begin{array}{r}85 \\
176 \\
74 \\
216 \\
>1 \\
>1\end{array}$ & $\begin{array}{c}2.5 \\
2.0 \\
1.3 \\
14.0 \\
4.0 \\
0.55\end{array}$ & $\begin{array}{r}1 \\
1 \\
\mathrm{~N} \\
\mathrm{~N} \\
2 \\
<2\end{array}$ & $\begin{array}{r}3,300 \\
3,300 \\
890 \\
7,000 \\
>1 \\
>1\end{array}$ & $\begin{array}{r}290 \\
1,700 \\
710 \\
200 \\
1,000 \\
100\end{array}$ & $\begin{array}{r}860 \\
710 \\
21,000 \\
930 \\
>1 \\
1,000\end{array}$ & $\begin{array}{r}1,400 \\
1,200 \\
400 \\
600 \\
>1 \\
>1\end{array}$ & $\begin{array}{c}34.4 \\
264 \\
10.6 \\
324 \\
76 \\
59\end{array}$ & $\begin{array}{r}>1 \\
>1 \\
1,600 \\
>1 \\
>1 \\
>1\end{array}$ \\
\hline \multicolumn{12}{|c|}{ Mazatzal Wilderness Area } \\
\hline $\begin{array}{r}\text { MZ442RC } \\
\text { 442RD } \\
442 \mathrm{RI} \\
\text { 454RB }\end{array}$ & $\begin{array}{c}(9.4) \\
(7.5) \\
(10.0) \\
2.5\end{array}$ & $\begin{array}{l}0.15 \\
0.05 \\
0.10 \\
0.25\end{array}$ & $\begin{array}{r}790 \\
450 \\
460 \\
>1\end{array}$ & $\begin{array}{r}13.0 \\
50.0 \\
24.0 \\
0.6\end{array}$ & $\begin{array}{r}2,200 \\
1,300 \\
730 \\
>1\end{array}$ & $\begin{array}{r}6,500 \\
4,700 \\
4,900 \\
>1\end{array}$ & $\begin{array}{r}38,000 \\
58,000 \\
27,000 \\
>1\end{array}$ & $\begin{array}{r}950 \\
2,100 \\
900 \\
320\end{array}$ & $\begin{array}{l}>1 \\
>1 \\
>1 \\
>1\end{array}$ & $\begin{array}{l}20 \\
60 \\
25 \\
>1\end{array}$ & $\begin{array}{l}>1 \\
>1 \\
>1 \\
>1\end{array}$ \\
\hline \multicolumn{12}{|c|}{ Hells Gate Roadless Area } \\
\hline MZ491RA & 0.3 & $\mathbf{N}$ & 12.8 & 0.9 & 140 & 17,000 & 65 & 300 & 48 & 2.35 & $>1$ \\
\hline
\end{tabular}


Table 4.--Atomic Absorption analysis of pyrite bearing rhyolite and metasediment rock samples from McFarland Canyon, Maricopa County, Arizona

[A11 values reported in parts per million. See Table 1 for description of samples. (The following qualifiers are used in reporting the data: $N$, not detected at the limit of determination; <, detected, but below the limit of reproducible determination for the standards used.]

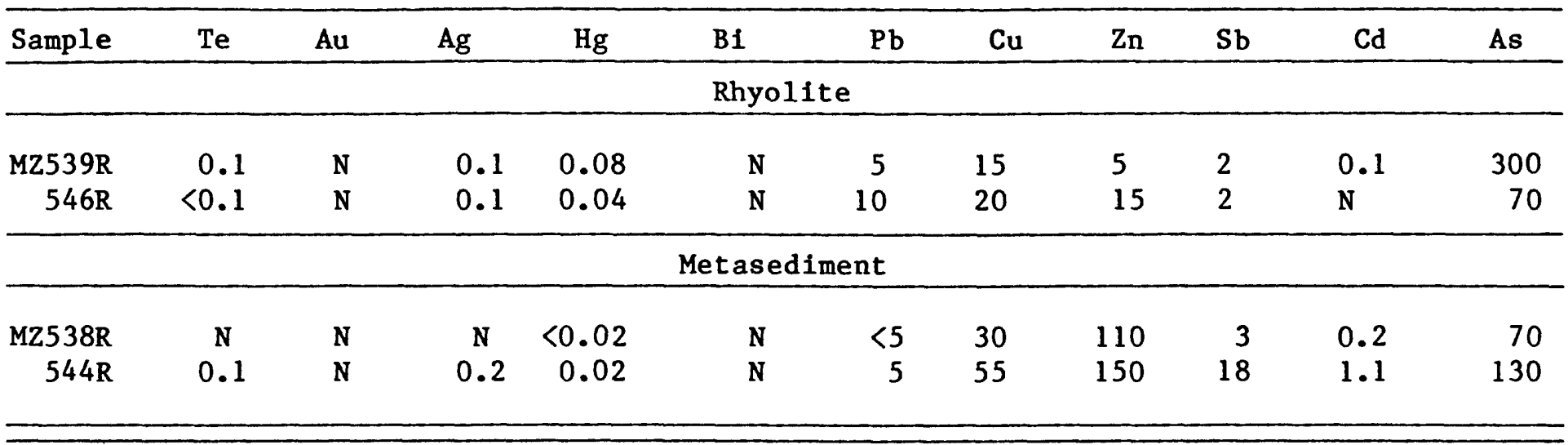

(10) 
Analysis of rock samples with pyrite being the only observed sulfide do not exhibit many indications of the geochemical suite associated with the arsenopyrite mineralization. Analyses of two samples of the rhyolite dikes and two samples of the meta-volcanoclastic sediments that appear to contain only pyrite showed no detectable gold and very little arsenic (Table 4). The absence of the geochemical suite associated with the gold and arsenopyrite suggests that the pyrite probably belongs to a separate mineralizing event, possibly associated with the intrusion of the rhyolite dikes. In the study of the Mazatzal Wilderness area pyrite mineralization was not commonly observed; where observed it was generally barren of the trace elements found in the mineralized areas in the Payson Granite. This also seems true in the McFarland Canyon-Story mine area.

The combination of field observations and chemical analyses of rock samples suggest another model for the mineralization seen at the McFarland Canyon-Story mine area. This model is related to the emplacement of the Proterozoic Payson Granite. Geochemical studies done during the study of the Mazatzal Wilderness indicate that the Payson Granite is a tin granite and a late hydrothermal event was part of its emplacement history. This late hydrothermal phase included the deposition of complex copper-silver sulfosalts and arsenopyrite containing antimony, lead, gold, mercury, bismuth, and tellurium; the same geochemical suite found in the $M c F$ arland Canyon-Story mine area. This suite is common to all mineralized areas found in the Payson Granite, thus it seems logical to assume that the arsenopyritegold mineralization seen in the M CFarland Canyon-Story mine area is also related to the late hydrothermal event in the Payson Granite. Several other observations support this model. Arsenic is also the most abundant trace element in the mineralized areas observed in the Payson Granite, commonly in the form of arsenopyrite veins and as secondary scorodite. Table 2 shows the similarity of trace element content of arsenopyrite samples from mineralized areas in the Payson Granite and arsenopyrite samples from the $M c F a r l a n d$ Canyon-Story mine area. Table 3 shows this same relationship in samples of secondary mineralization from these areas. There are also structural similarities. Mineralization in the Payson Granite occurs along northeast trending structures that, for the most part, contain quartz veining; a similar situation exists in the McFarland Canyon-Story mine area. Also, mineralization related to the Payson Granite in the Mazatzal Wilderness and south of the Hells Gate Roadless Areas often extends out into the surrounding metasediments along the northeasttrending structures. The Sheep Mountain fault, less than $2 \mathrm{~km}$ north of the $M C F$ arland Canyon-Story mine area, is a major northeast-trending structure, that cuts the Payson Granite. Mineralized areas near the fault contain the diagnostic geochemical suite.

Two other elements related to arsenic-gold mineralization are bismuth and boron. Bismuth occurs in virtually all the arsenopyrite samples collected during this study and in arsenopyrite samples collected during the study of the Mazatzal Wilderness Area (Table 2). Bismuth is commonly found in sulfides related to tin granites (Taylor, 1979) and its presence here provides another tie between the Payson Granite mineralization and that observed at the McFarland Canyon-Story mine area. Boron was also common in samples from both areas. In areas of mineralization in and around the $P$ ayson Granite, tourmaline was observed as veinlets, large clots and rosettes, and as fracture and surface coatings. Although no tourmaline was observed in the $M c F$ arland Canyon-Story mine area, twelve of the mineralized samples contained $0.2 \%$ or greater boron. In this geologic environment tourmaline is the only boron mineral that would be expected and it is assumed that it is present. Another element common to all these areas is mercury. Mercury occurs in amounts of as much as $90 \mathrm{ppm}$ in complex copper sulfides found in mineralized zones in the Payson Granite, occurs in anomalous amounts in almost all of the samples taken in this 
study, and occurs as cinnabar in the Sunflower mining district, adjacent to the McFarland Canyon-Story mine area. This cinnabar mineralization, although occuring in the Proterozoic $X$ rocks of the Alder Formation, is not thought to be Proterozoic in age. More likely the mercury mineralization is the result of mercury being distilled from earlier deposited complex polymetallic sulfides and redeposited as cinnabar. Support for this concept is found in the fact that mercurian copper sulfides occur in the lower levels of the Ord mercury mine about $10 \mathrm{~km}(7 \mathrm{mi})$ east of $M \mathrm{cF}$ arland Canyon (J. N. Faick, 1959). This suggests that the cinnabar found in the Sunflower mining district, although Tertiary (?) in age, had its origins in the late hydrothermal phase of the Payson Granite.

\section{Conclusions}

Based on field observations and chemical data from this study and on data from the study of the Mazatzal Wilderness Area, the mineralization seen in the $M c F a r l a n d$ Canyon-Story mine area is thought to be related to a late hydrothermal phase of the Proterozoic Payson Granite. The geochemical suite of arsenic, copper, lead, and antimony with gold, silver, mercury, bismuth, and tellurium, associated with mineralization in the $\mathrm{MCF}$ arland $\mathrm{Cany}$ on-Story mine area is the same elemental suite that occurs in mineralized areas in and adjacent to the Payson Granite. Similar structural trends and extensive silicification and quartz veining are common to both areas. The Payson Granite is exposed within a few kilometers (miles) to the north and east of $M c F$ arland $C$ anyon and is thought to be in the subsurface in the $M c F$ arland $C$ anyon area. To test this model, detailed chemistry of the rhyolite dikes to establish their relationship, if any, to the Payson Granite and alteration studies to establish the relationship of the mineralization in McFarland Canyon to mineralization at the Story mine are needed. The influence of the Sheep Mountain fault on the mineralizing system is also unknown.

\section{References Cited}

Chao, T. T., Sanzalone, R. F., Hubert, A. E., 1978, Flame and flameless atomic absorption determination of tellurium in geologic material: Analytical Chimica Acta, vo. 96, p. 251-257.

Faick, J. N., 1958, Geology of the Ord mine, Mazatzal Mountains quicksilver district, Arizona: U.S. Geological Survey Bulletin 1042-R, p. R685-R698.

Grimes, D. J., and Marranzino, A. P., 1968, Direct-current arc and alternating-current spark emission spectrographic field methods for the semiquantitative analysis of geologic materials: U.S. Geological Survey Circular 591, 6 p.

Taylor, R. G., 1979, Geology of tin deposits: New York, Elsevier, 543 p.

Thompson, C. E., Nakagawa, H. M., and Van Sickle, G. H., 1968, Rapid analysis for gold in geologic materials in Geological Survey research 1968: U.S. Geological Survey Professional Paper 600-B, p. B130-B132.

Vaughn, W. W., and McCarthy, J. H., Jr., 1964, An instrumental technique for the determination of submicrogram quantitites of $\mathrm{Hg}$ in soils, rocks, and gas, in Geological Survey research 1964: U.S. Geological Survey Professional Paper 501-D, p. 123127.

Viets, J. G., 1978, Determination of silver, bismuth, cadmium, copper, lead, and zinc in geologic materials by atomic absorption spectrometry with tricaprylyl-m e thyla m monium chloride: Analytical Chemistry, v. 50, no. 8, p. 1097-1101.

Ward, F. N., Lakin, H. W., Canney, F. C., and others, 1963, Analytical methods used in geochemical exploration by the U.S. Geological Survey: U.S. Geological Survey Bulletin 1152, $100 \mathrm{p}$. 
Wrucke, C. T., Marsh, S. P., Conway, C. M., Ellis, C. E., Kulic, D. M., and Moss, C. K., 1983, Mineral resource potential of the Mazatzal Wilderness and Contiguous Roadless Areas, Gila, Maricopa, and Yavapai Counties, Arizona: U.S. Geological Survey Miscellaneous Field Studies $M$ ap [in press].

\footnotetext{
Appendix

A total of 69 rock samples were collected from the McFarland-Story mine area and analyzed. For each sample, a representative hand specimen was reserved and the remainder crushed. An $85 \mathrm{~g}(3 \mathrm{oz})$ container of the crushed material was pulverized, and reserved for analysis. The remaining crushed bulk sample was placed in storage. The pulverized sample was analyzed by spectrographic and atomic absorption techniques.

Spectrographic results were obtained by visual comparison of spectra derived from the sample against spectra obtained from standards. The matrix of the standards is made from pure oxides or carbonates. Trace elements are added to the matrix so that the concentrations are geometrically spaced over any given order
}

of magnitude, thus the range of concentrations normally found in naturally occurring samples are bracketted. When comparisons are made with sample films for semiquantitative use, reported values are rounded to $100,50,20,10$, and so forth. Those samples whose concentrations are estimated to fall between the above values are arbitrarily given values of $70,30,15,7$, and so forth (Grimes and Marranzino, 1968). The precision of the method is approximately plus or minus one reporting unit at the 83 percent confidence level and plus or minus two reporting units at the 96 percent confidence level (Motooka and Grimes, 1976). Values determined for the major elements (magnesium, calcium, iron, and titanium) are given in weight percent; all others are given in parts per million (micrograms/gram). Atomic absorption analysis for cadmium, bismuth, antimony, zinc, arsenic, mercury, gold, copper, silver, lead, and tellurium were performed on each sample. Table 5 lists all elements determined, lower limits of detection and references for methods of analysis. Results from both spectrographic and atomic absorption analyses are given in Table 6. Sample localities are shown in Plate 1. 
Table 5.--Elenents determined, lower limits of detection, and references for methods of analysis for rock samples from the MCFarland Canyon-Story mine area, Mazatzal Wilderness Area, and Hells Gate Roadless Area, Arizona

[pct (percent), ppm (parts per million)]

Clolumn Lower Limit of Detection

Designation Rock Rerence

D.C. arc/spectrographic analysis by E. F. Cooley, C. Forn, and M. S. Erickson

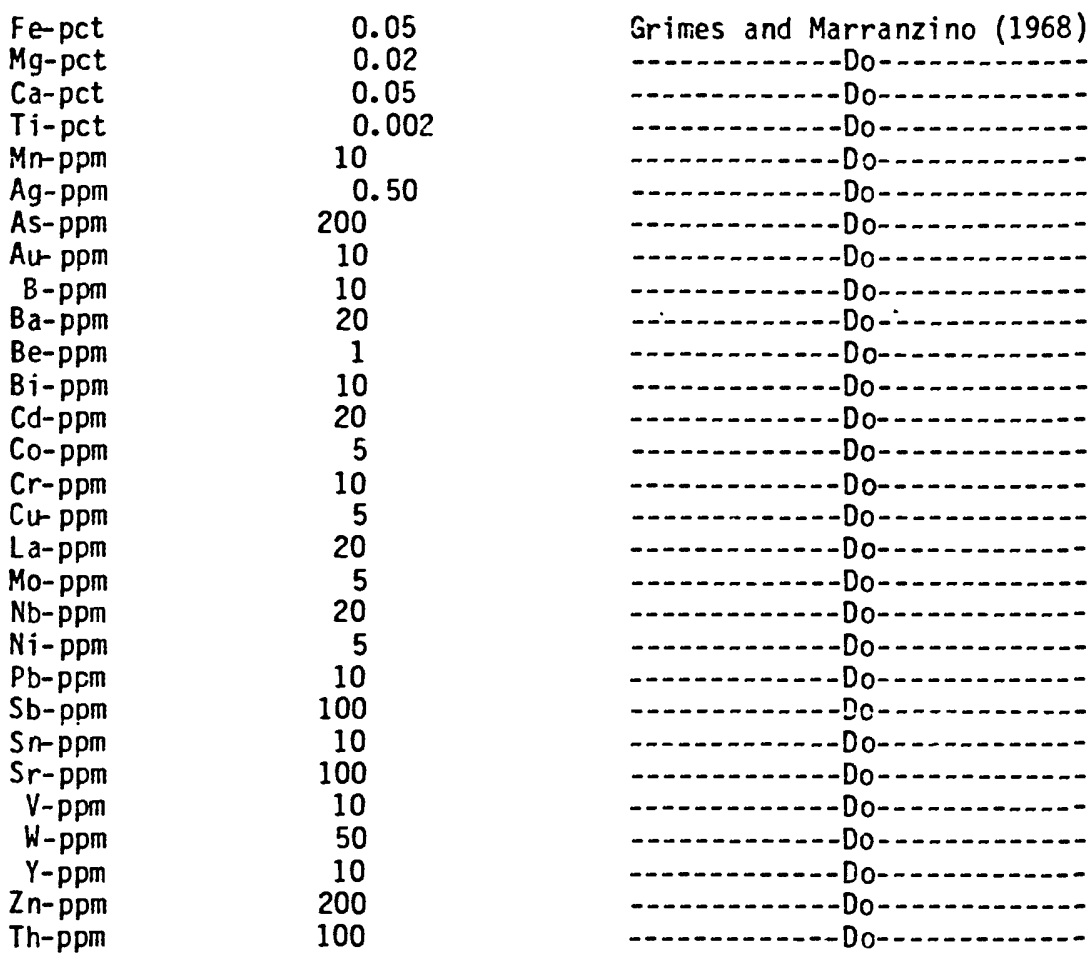

Atomic Absorption Spectrometry

$\mathrm{Cu}, \mathrm{Pb}, \mathrm{Zn}, \mathrm{Ag}, \mathrm{Cd}$, and $\mathrm{Bi}$ determined by $\mathrm{R}$. M. O'Leary, T. Roemer, B. Arbogast, R. Leinz, and J. Grey;

Au determined by $S$. Royse and J. Grey;

$\mathrm{Hg}$ instrument determination by R. M. O'Leary;

Te determined by T. Roemer, B. Arbogast

\begin{tabular}{|c|c|c|c|}
\hline $\begin{array}{l}\text { Clu-ppm } \\
\text { Pb-ppm } \\
\text { Zn-ppm } \\
\text { Ag-ppm } \\
\text { Cd-ppm } \\
\text { Bi-ppm } \\
\text { As-ppm } \\
\text { Sb-ppm } \\
\text { Au-ppm } \\
\text { Hg-ppm } \\
\text { Te-ppm }\end{array}$ & - & $\begin{array}{l}5 \\
5 \\
5 \\
0.05 \\
0.1 \\
2 \\
5 \\
1 \\
0.05 \\
0.02 \\
0.1\end{array}$ & $\begin{array}{l}\text { modified from Viets (1978) } \\
\text { Thompson and others (1968) } \\
\text { modified from Vaughn \& McCarthy (1964) }\end{array}$ \\
\hline \multicolumn{4}{|c|}{ Colorimetric Arsenic determined by B. Arbogast } \\
\hline As-ppm & & 10 & Ward and others (1963) \\
\hline
\end{tabular}




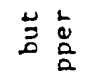

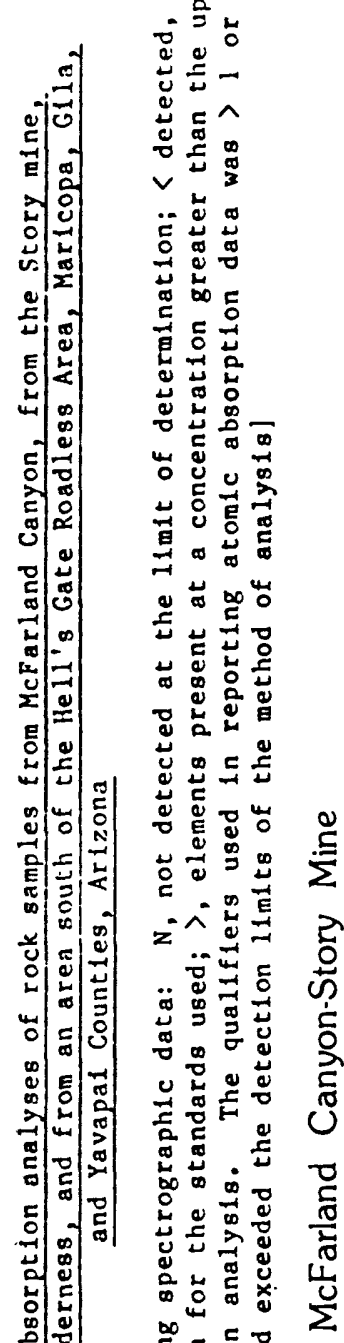

帘

E⿱

옴응응

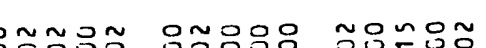

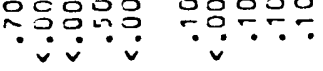

$\dot{0}$
$\dot{0}$
$\dot{0}$
0

ํํํํำ

ํํำํำ ํํำ

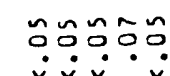

ํํํํํํํำำ

ำํำำำำ

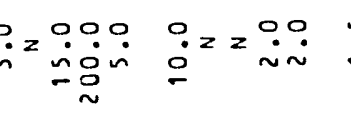

$\because \because 2 \because 0$

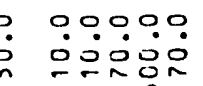

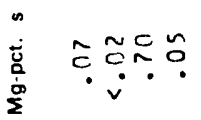

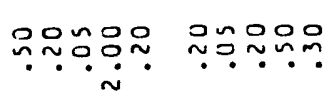

nonon

noono

웅

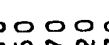

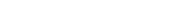

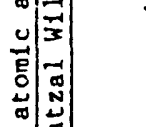

嵩

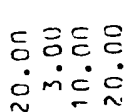

c.0000

00000

บำด

$\because$

00000

00000

00090

00000

0000

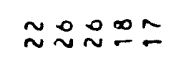

エะュュュ

$\simeq ロ \Xi ニ \bar{\sim}$

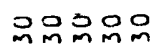

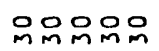

있윰임요

え

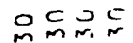

こニここま

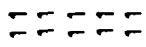

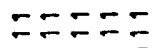

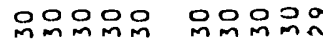

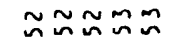

กักญ゚ำ

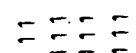

$\because-\bar{x}$

$\underset{m \sim ⿻}{\infty} \underset{\sim}{\infty} \underset{\sim}{\infty} \stackrel{x}{\sim}$

noo $2=$

$m m m m m$

$\sin a=$

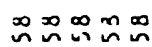

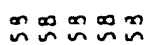

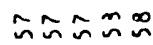

$\hat{\operatorname{con}} \tilde{\sim} \tilde{\sim} \tilde{s}$

mming

minmmin

minnmin

的的的前

-ニ-テ=

ニニニニ

น N

우웅뭉

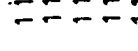

$=0 \div \div$

$0000 \infty$

的踏品品

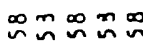

エேン゚ロ

ニํㅇ

更

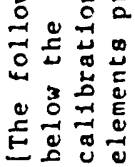

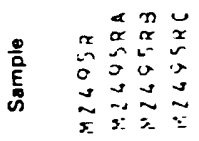

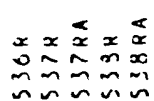

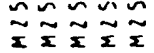

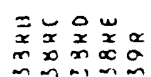

$\approx \approx \approx \approx \approx$

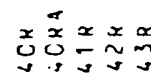

$\approx \sim \sim \sim \sim \Sigma$

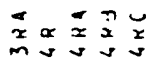

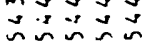
ก. $\tilde{x} \geq \tilde{x}$

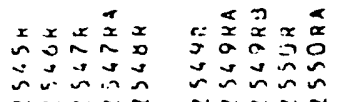

$\underset{x}{x} \approx \approx \alpha x$

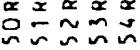
$\tilde{x} \approx \sim \approx n$ 


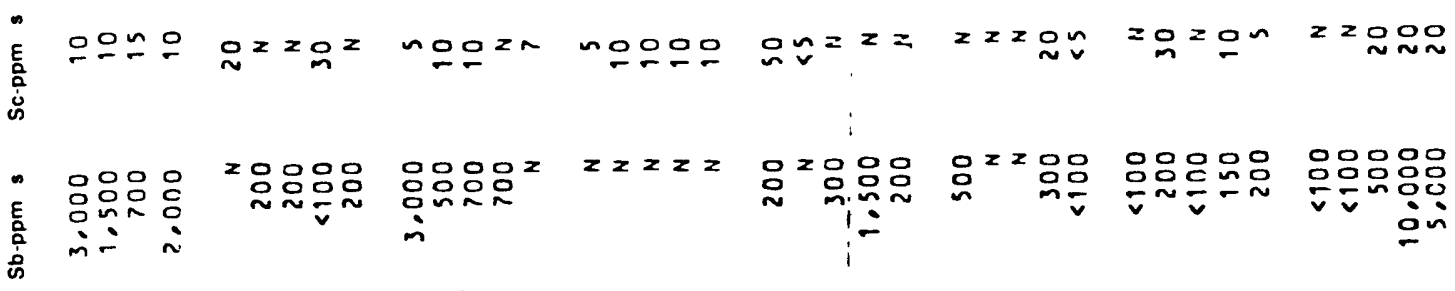

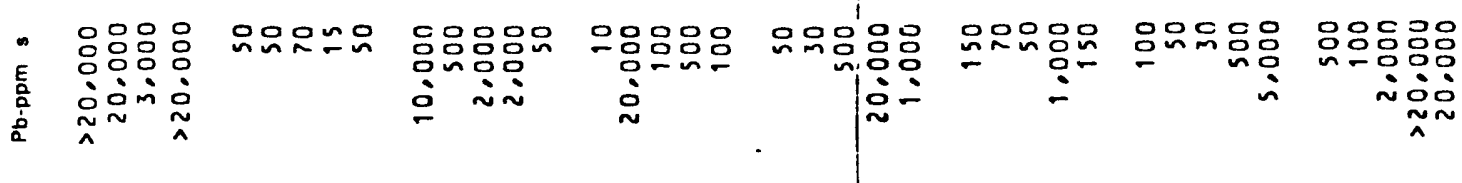

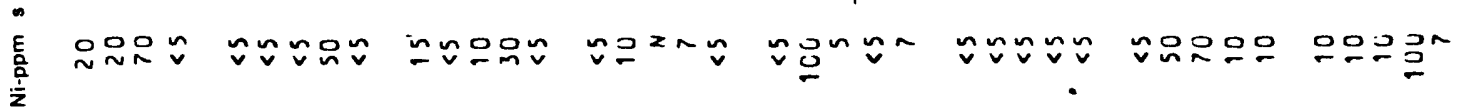

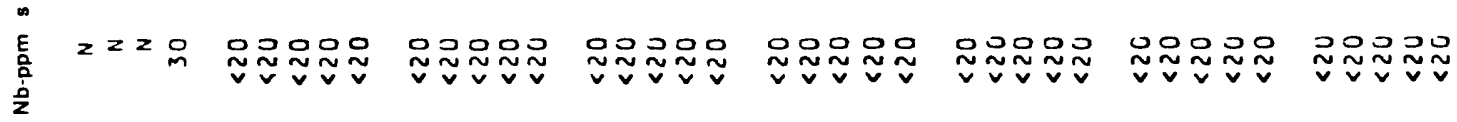

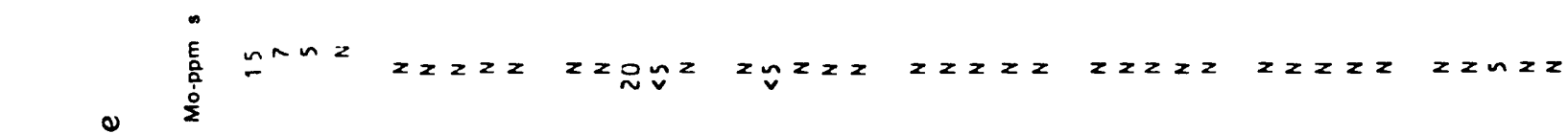

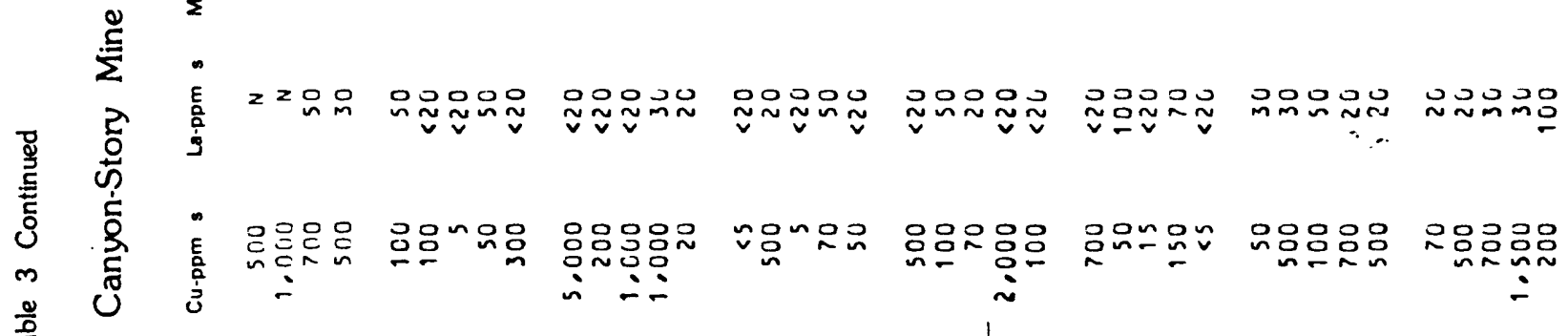

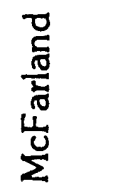

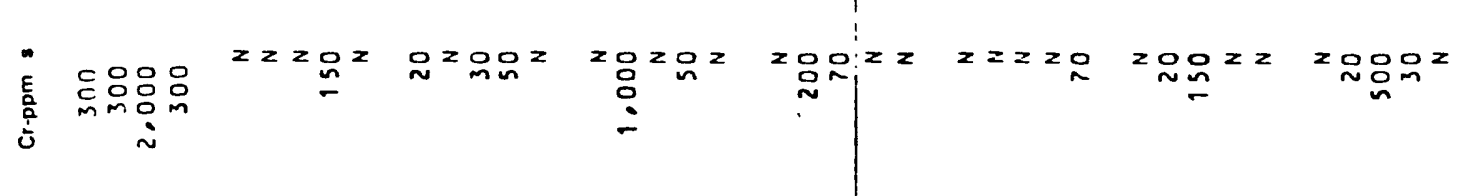

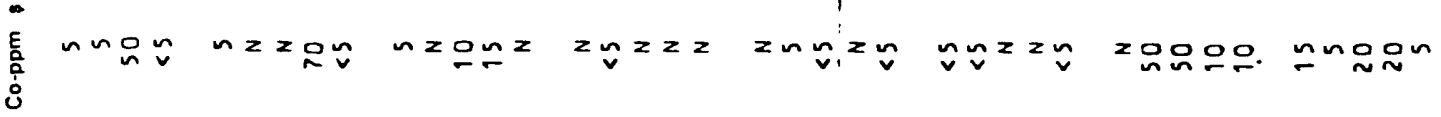
$E$
$E$

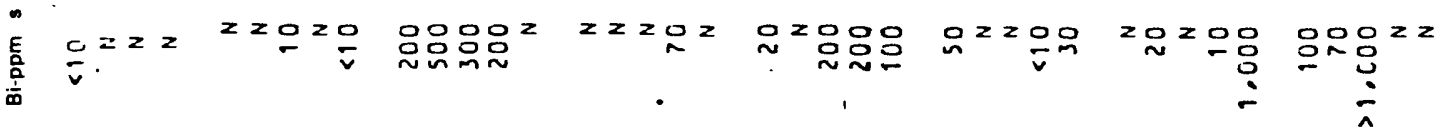
E

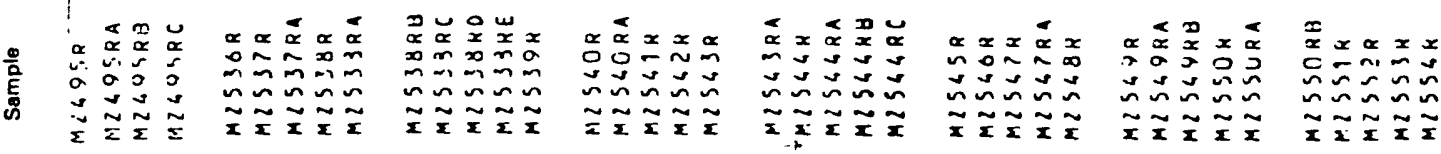


E

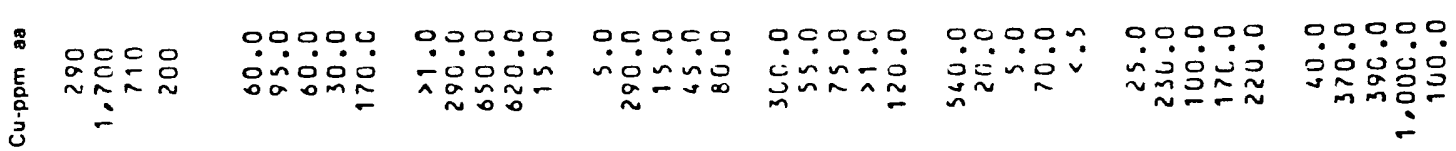
亳

: $\stackrel{\text { ì }}{\dot{3}}$

$\stackrel{\mathscr{E}}{\Sigma}$

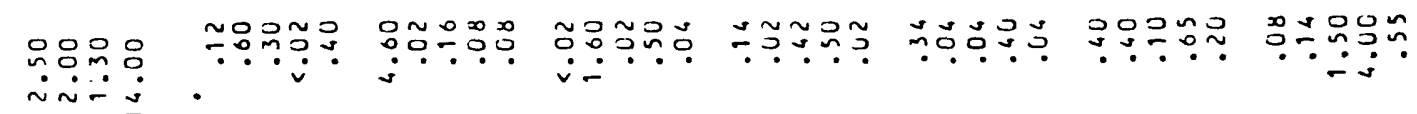

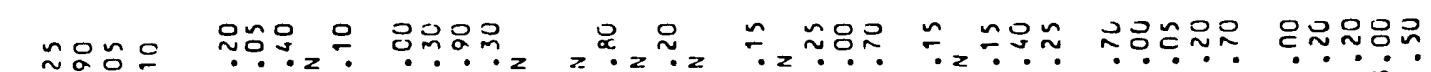

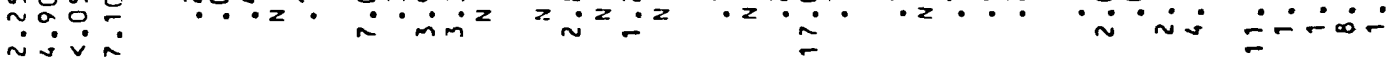

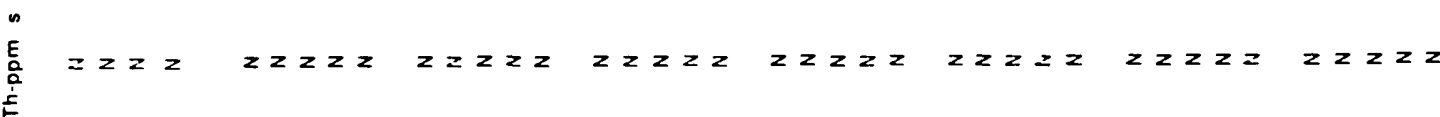

高

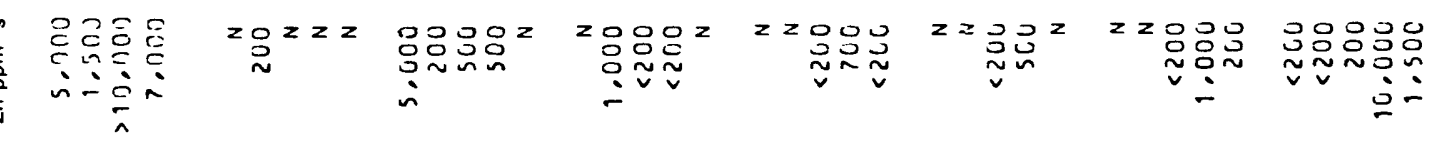

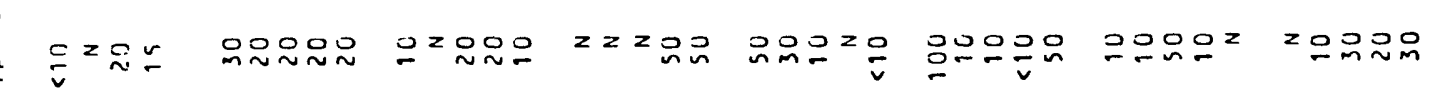
产

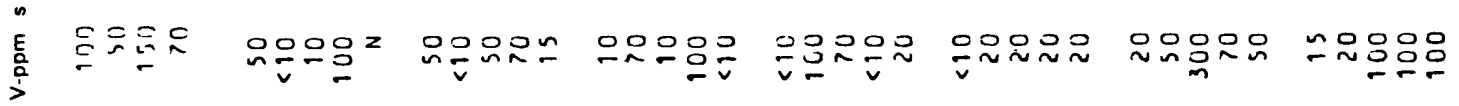
言

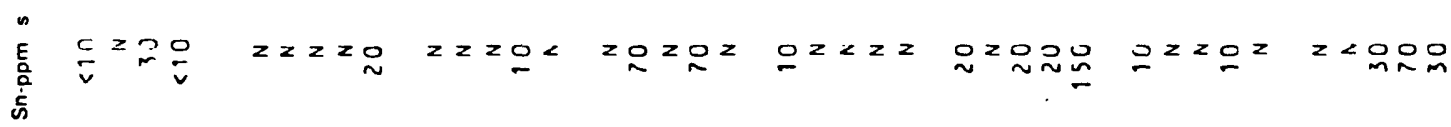

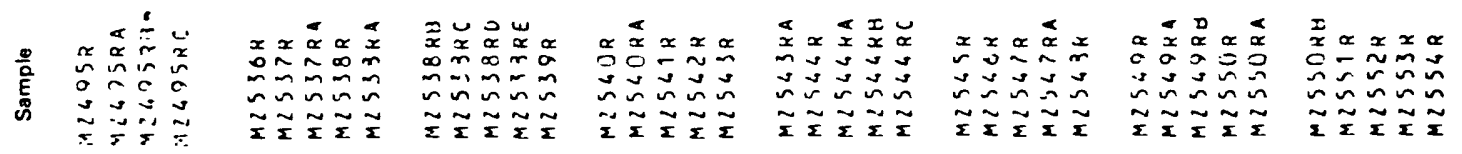




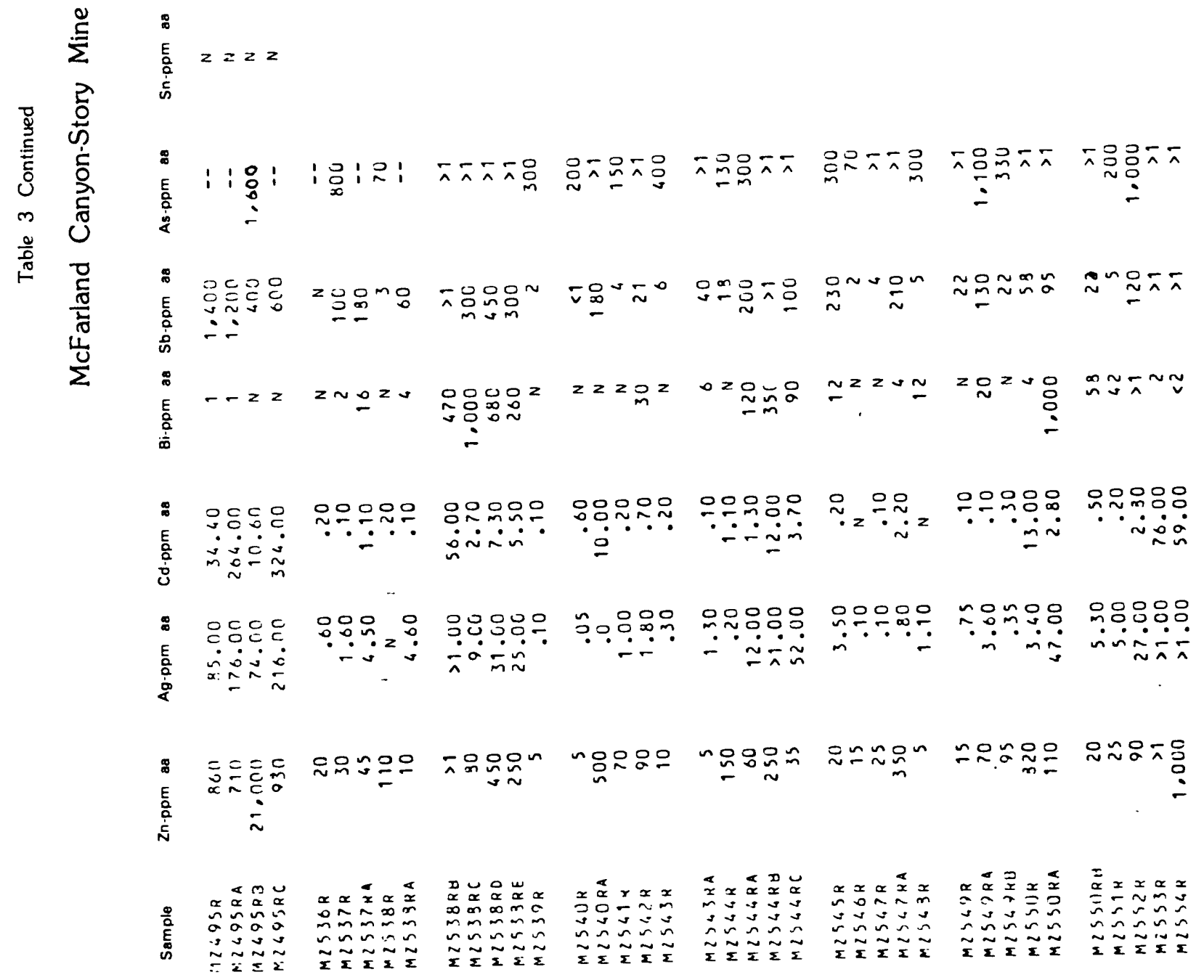




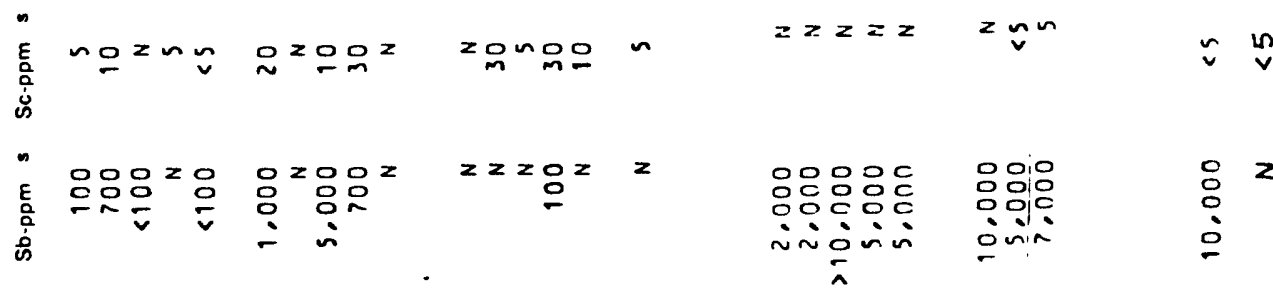

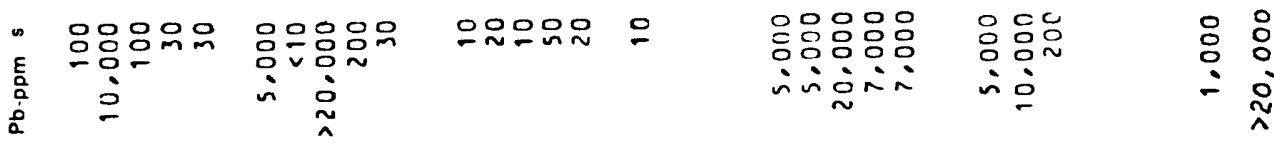

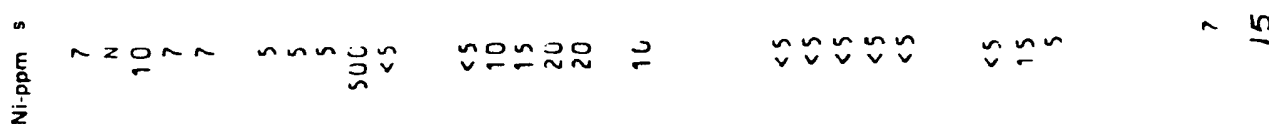

|

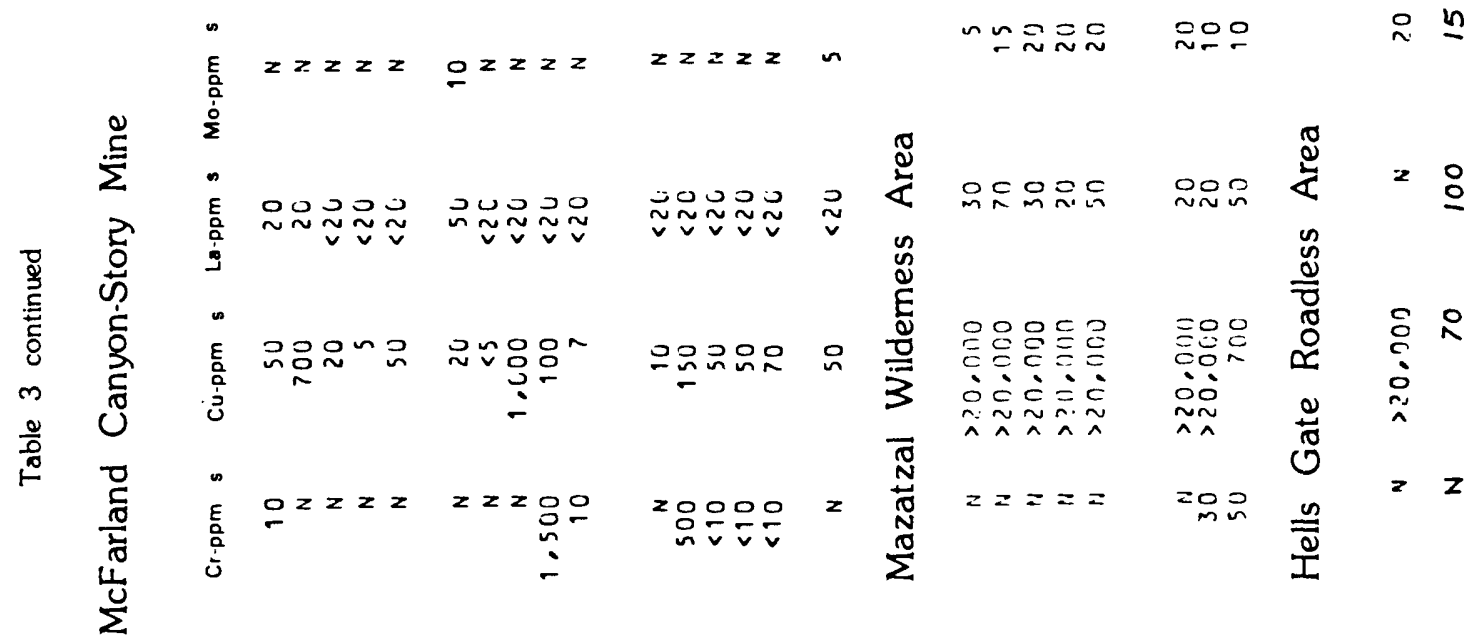

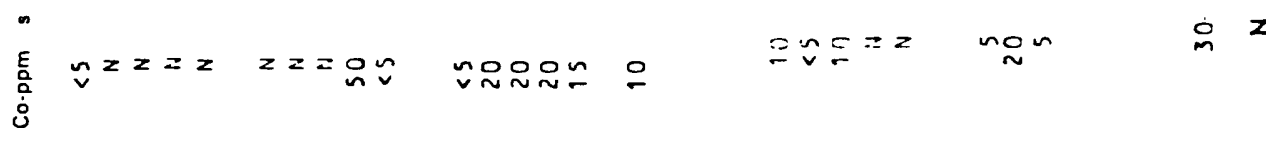

!

|

|

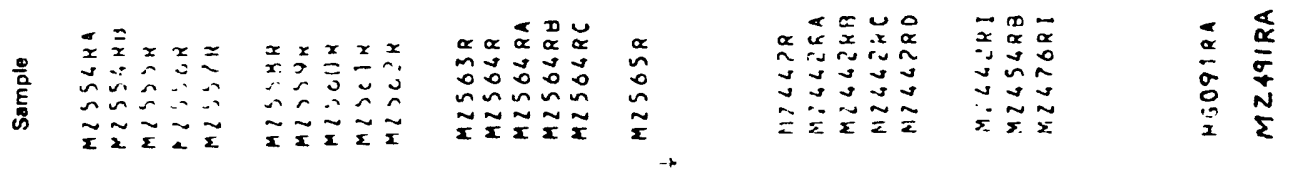


E

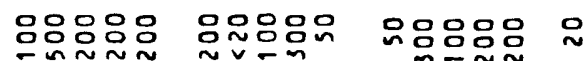

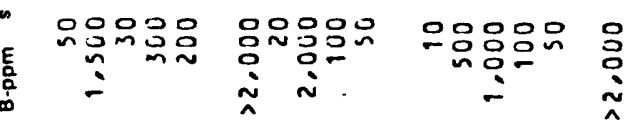

E

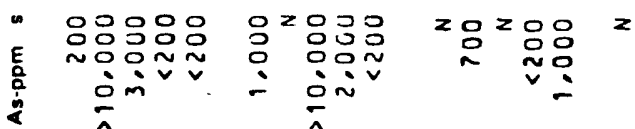

E

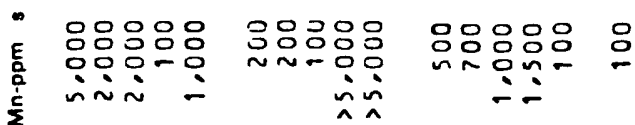

$\stackrel{0}{\Xi}$

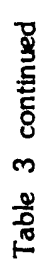

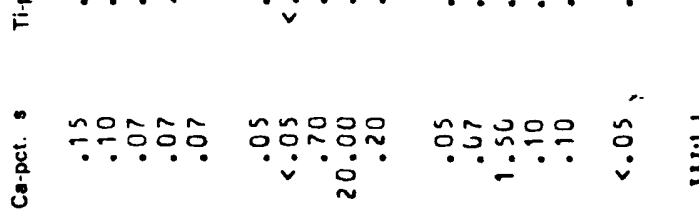

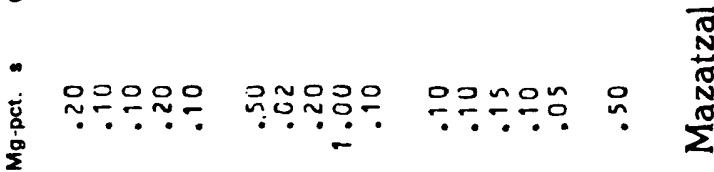

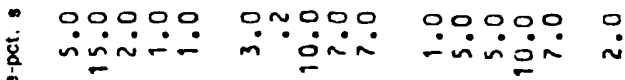

迩

迹

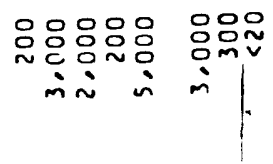

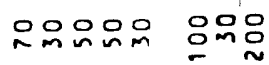

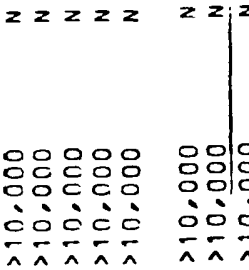

$\doteq z$

c.

$\therefore \frac{1}{1}$

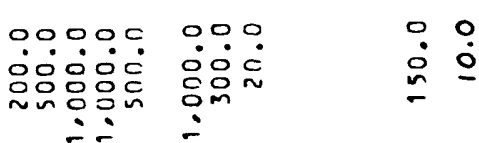

은은드응 응은

$\stackrel{\circ}{\grave{i}}$

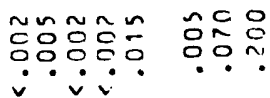

$\stackrel{8}{\mathbb{2}}$

㟧

ợ̆ọoñ.

\&

范

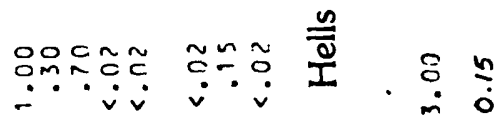<smiles>[CH]C</smiles>

응응응을 듣응응

움ㄴㅁ $\dot{\sim} \dot{\sim} \dot{\sim}$

$\stackrel{0}{\sim}$

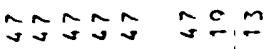

$\therefore \div$

च.

$\simeq=$

$\Xi \Xi \Xi \Xi \Xi こ \Xi こ$

$\equiv \equiv$

$\tilde{\sim} \tilde{n} \tilde{n} \tilde{n}=\bar{J}$

$x, \alpha \infty \infty$ in $\simeq$ -

$\approx$ in

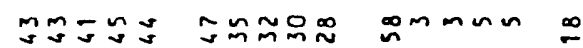

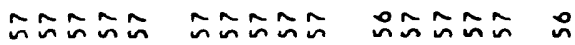

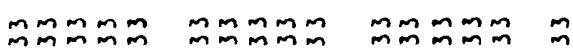

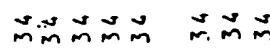

$m n$

$\dot{m} \ddot{m}$

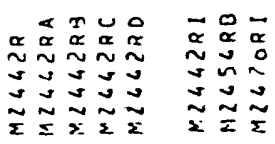

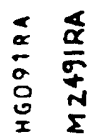




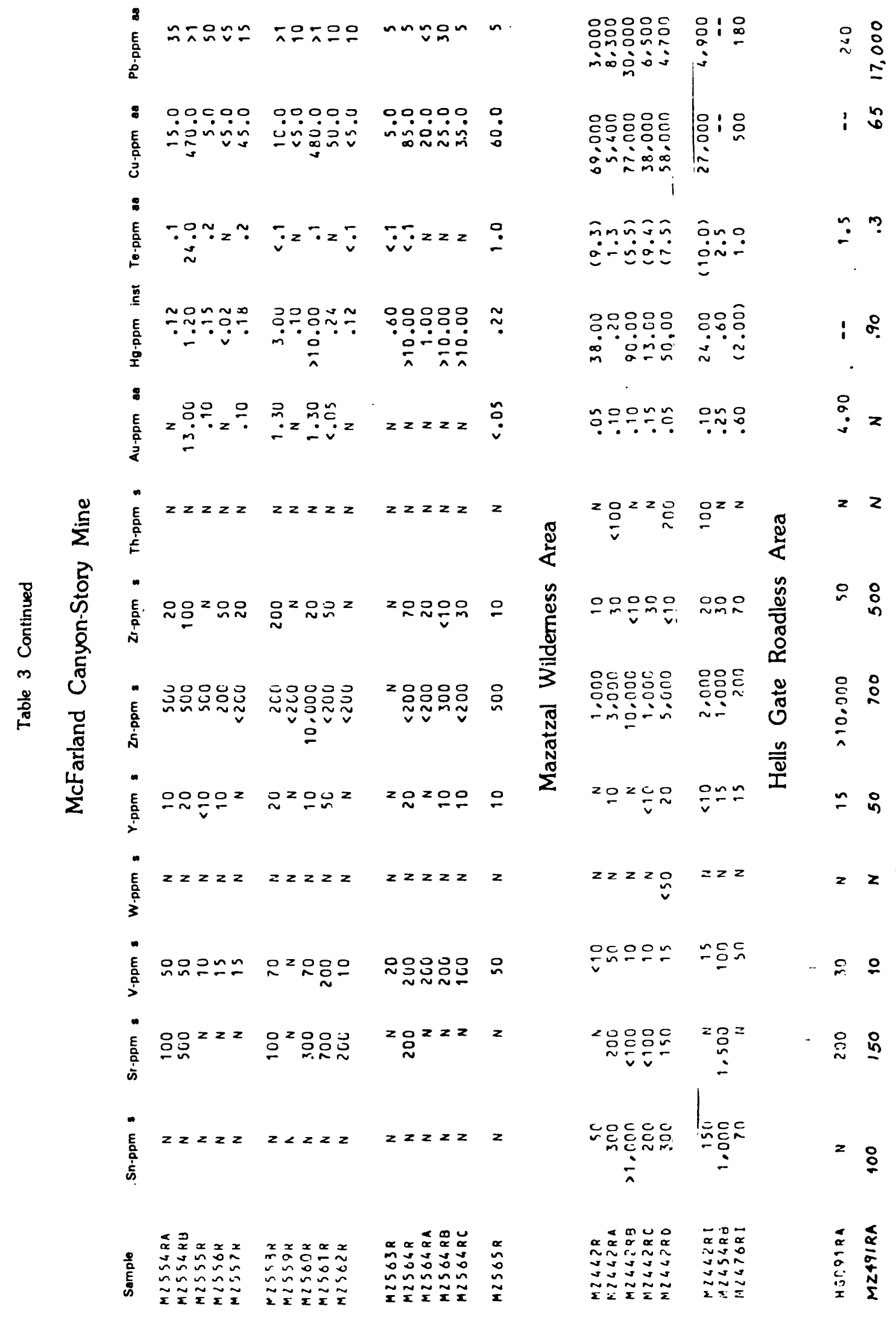




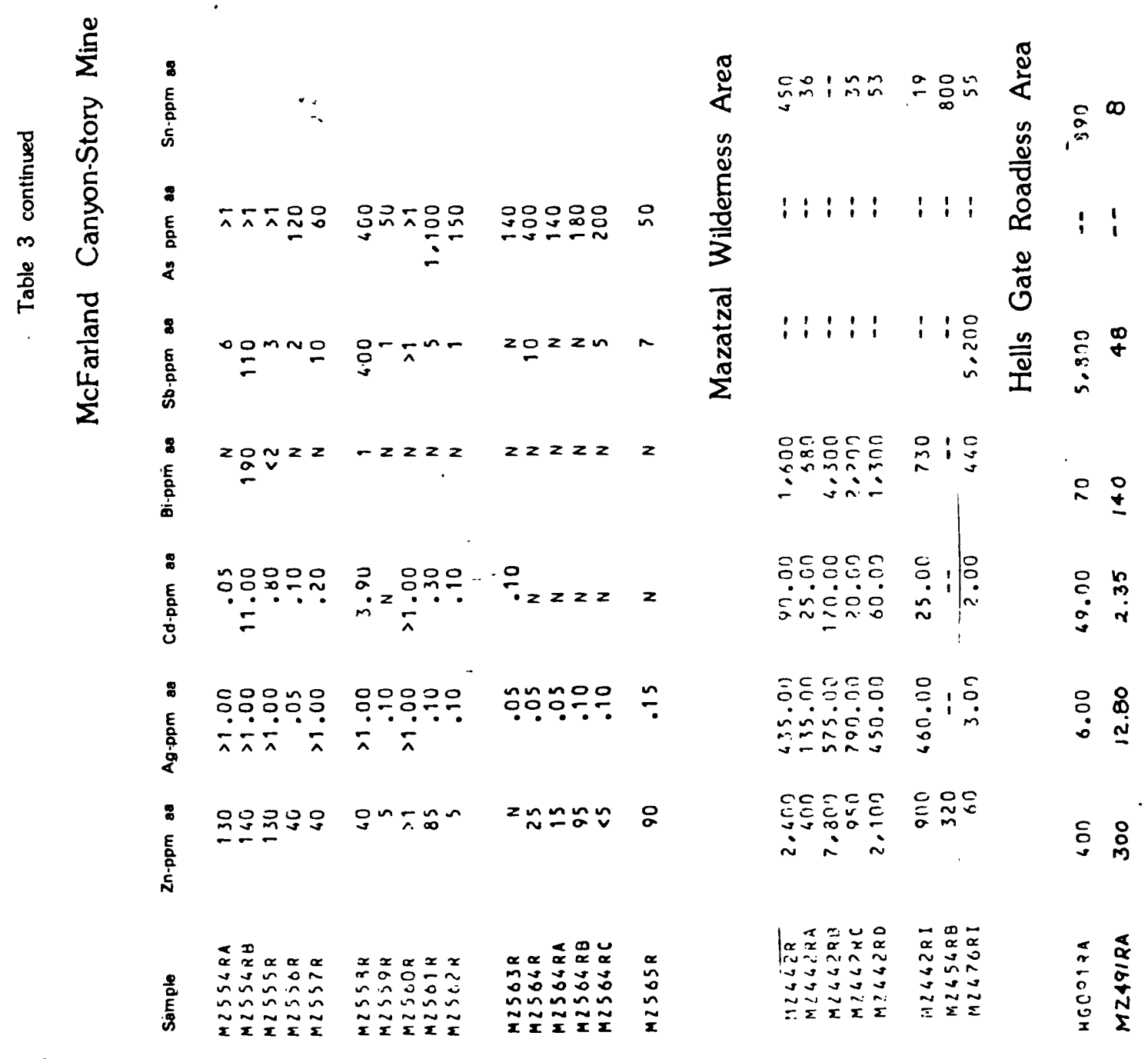

